\title{
Fra Grundtvig-litteraturen:
}

\section{Regner Birkelund, Frihed til fælles bedste: En oppositionel stemme fra fortiden}

\author{
Af Carl Henrik Koch
}

Regner Birkelund, Frihed til falles bedste: En oppositionel stemme fra fortiden. Aarhus Universitetsforlag, Aarhus 2008, 685 s.

Store disputatser om Grundtvig er snarere reglen end undtagelsen. Det omfattende, mangesidige forfatterskab indbyder til det. Selv kunne Grundtvig være prisværdig knap. I Politiske Betragtninger fra 1831 skrev han ligefrem, at tykke bøger og især sådanne, der angår politiske emner, sædvanligvis ikke hører til de bedste (54).

Birkelunds afhandling er et bidrag til beskrivelse af Grundtvigs politiske tænkning med hovedvægt på begrebet om frihed, som jo spiller en afgørende rolle både i Grundtvigs overvejelser over den bedste styreform, i hans pædagogiske tænkning og i hans forsøg på at karakterisere det nordiske og folkelige til forskel fra det tyske, franske og romerske. I sit berømte essay om Bentham skrev John Stuart Mill, at $\mathrm{i}$ den politiske filosofi stilles tre fundamentale spørgsmål, nemlig: (1) Hvilken autoritet skal et folk være underkastet til sit eget bedste?, (2) Hvordan skal det anspores til at adlyde denne autoritet?, og (3) Hvordan skal misbrug af autoriteten undgås? Som bekendt var Grundtvigs svar på det første spørgsmål - med Tine Damsholts fra J. A. Seip lånte udtryk - den opinionsstyrede enevælde, og svaret på de to sidste var oplysning, som den skulle formidles af den skole for folket og livet, som Grundtvig propaganderede for. Derfor var hans politisk-filosofiske overvejelser tæt knyttet til hans pædagogiske utopier, og derfor kan hans overvejelser over frihed ikke afhandles kort. Men heri ligger ikke, at længden af Birkelunds afhandling er berettiget. Hele afsnit kunne med fordel have været udeladt, for eksempel afsnittet om kvindens frigørelse, og de mange kursiveringer i teksten, som hæmmer læsningen, og som synes at være udtryk for, at forfatteren mener, at læseren ikke formår at læse indenad, forstærker kun indtrykket af, at der er overmåde mange gentagelser i bogen.

Disputatstraditionen tro indleder Birkelund sin afhandling med lidt forskningshistorie. En af konklusionerne er her, at der synes at være 
mange nøgler til Grundtvigs tankeverden (32). Alligevel synes forfatteren at lægge sig fast på, at kardinalpunktet i Grundtvigs forfatterskab er etisk, idet det grundlæggende spørgsmål er, hvordan det gode samfund eller det samfund, der virker med det fælles bedste for øje, skal sikres. Skønt ordene "det gode samfund" og "det fælles bedste" i al deres vaghed optræder kursiveret utallige gange $i$ afhandlingen, forsøges intetsteds en præcisering. Af de i den forskningshistoriske oversigt nævnte værker savner man Erik Møllers udmærkede — og kortfattede — Grundtvig som Samtidshistoriker fra 1950.

Efter den forskningshistoriske oversigt følger en snes sider under overskriften "Metodeovervejelser". Her knytter Birkelund an til Gadamers hermeneutik, men det eneste, der kommer ud af disse overvejelser, er, at læsningen af enhver tekst forudsætter en "forforståelse". Birkelunds forforståelse er, at Grundtvigs begreb om det gode samfund er inspireret af såvel Platon som Aristoteles. Jeg skal senere vende tilbage til, om denne "forforståelse" eller hypotese i afhandlingen etableres som en egentlig tese, men skal allerede nu bemærke, at det er yderst vanskeligt at vise, at en person ikke er inspireret af et af vedkommende kendt forfatterskab eller synspunkt, da for eksempel også en fejlagtig forståelse af pågældende forfatterskab eller synspunkt kan have virket inspirerende. Omvendt kan det være lige så vanskeligt at fastslå, at der foreligger en inspiration eller påvirkning, hvis det ikke er eksplicit angivet. Blandt de metodiske overvejelser savner man derfor en egentlig redegørelse for, hvilke kriterier der lægges til grund for at fastslå påvirkning eller inspiration. Birkelunds praksis synes at vise, at hans argumentation for et påvirkningsforhold er baseret på en sproglig overensstemmelse mellem relevante tekststeder hos Grundtvig og nyere oversættelser til dansk af tekster tilskrevet Platon og Aristoteles uden hensyntagen til den historiske kontekst, som affødte Platons og Aristoteles' politisk-filosofiske overvejelser, og til det forhold, at der rent semantisk er store problemer forbundet med en oversættelse af oldgræske tekster til et moderne europæisk sprog. Det har altid været sund og normal videnskabelig praksis inden for humanistisk forskning, at gå til kilderne (ad fontes!) og hverken at bygge sin argumentation på oversættelser eller hente citater fra sekundære kilder uden at oplyse, hvor i det primære kildemateriale det citerede kan findes. For blot at nævne nogle eksempler på det sidste: På side 178 anføres et Grundtvig-citat om græsk tolerance hentet fra J. P. Bangs Grundtvig og England (1932) og angiveligt stammende fra et udkast til Nordens Mythologi (1832), og på side 552 anføres et for Birkelunds tese relevant Grundtvig-citat, som er hentet hos Kaj Thaning. I overensstemmelse med almindelig humanistisk citationspraksis burde forfatteren havde fundet stederne hos Grundtvig selv, ikke mindst fordi det i så 
fald ville være muligt for den interesserede læser at forstå citatet på baggrund af sammenhængen. Tilsvarende citeres på side 83 Adam Smith ud fra en sekundær kilde.

Brugen af oversættelser vanskeliggør også den grundige læsers bestræbelse på at kigge forfatteren i kortene, ikke mindst fordi de standardangivelser af sidetal, som for eksempel litteraturen om Platon, Aristoteles og Kant opererer med, ikke er angivet. Forfatteren undgår overalt konsekvent at henvise til standardudgaver undtagen i forbindelse med Grundtvig. Brugen af danske oversættelser nødvendiggør, at en kritisk læser, som ikke ønsker at være afhængig af en ud af flere ofte afvigende oversættelser, må gå tilbage til originalteksten for at afklare, om der er tekstmæssigt belæg for forfatterens forståelse af det citerede. Jeg skal senere give et enkelt eksempel herpå.

Fra side 75 til side 130 får læseren under overskriften "Politiskfilosofiske hovedstrømninger" en bred gennemgang af udvalgte dele af europæisk politisk tænkning fra Locke til Marx. Afsnittet skal, med forfatterens ord, give "belysningskilde og vurderingsgrundlag for Grundtvigs tænkning" (74). Stort set betyder det, at forfatteren jævnfører udtalelser af Grundtvig med ytringer fra oversættelser til dansk af enkelte politiske tænkeres produktion.

I afsnittet optræder der en del mærkelige fejl. For blot at nævne nogle eksempler: På side 79 tilskrives Locke den traditionelle tredeling af den politiske magt $\mathrm{i}$ den lovgivende, den dømmende og den udøvende magt. Den stammer nu fra Montesquieu, som har misforstået Locke, der skelnede mellem den lovgivende, den dømmende og den føderative magt (se Laslette 1967). På side 81 tilskrives Locke et arbejde med titlen Political Writings forfattet i 1697 og først udgivet i 1963. Der tænkes på en samling Locke-tekster med denne titel udgivet af David Wotton i 1993 (årstallet rigtigt angivet i bibliografien). Det tekststykke, der refereres til, er "Draft of a Representation Containing a Scheme of Methods for the Employment of the Poor. Proposed by Mr. Locke, the $26^{\text {th }}$ October 1697", som blev publiceret første gang i 1789. Værre er det, at Birkelund på side 122 totalt fejltolker Hegel ved at identificere Verdensånden, som her kaldes "verdensfornuften", med "ideen". Verdensånden var undertiden Hegels betegnelse for historiens immanente dynamik, og Ideen (med stort "I"!) er resultatet af denne krafts virken, nemlig den absolutte selvbevidsthed, det vil sige sammenfaldet mellem menneskets begreb om tingene og tingene, som de er.

Den alvorligste mangel i dette afsnit er imidlertid, at Birkelund ser totalt bort fra den diskussion om ydre, det vil sige borgerlig, frihed, som udspandt sig omkring år 1800 med Kant og Fichte som de væsentligste bidragydere, og som herhjemme blev repræsenteret af $\mathrm{A}$. 
S. Ørsted med prisopgaven Over Sammenhangen mellem Dydelaerens og Retslarens Princip (1798) og hans prøveforelæsning ved Københavns Universitet "Hvorpaa er Strafferetten grundet, og efter hvilke Regler bør den udøves" trykt i Minerva (1800). Baggrunden for denne udeladelse synes at være Grundtvigs kendte kritik af den tyske idealisme for abstrakt begrebsdannelse og tænkning, en kritik, som adskillige Grundtvig-forskere ukritisk har overtaget. $\mathrm{Nu}$ er Kants, Fichtes og Ørsteds almene karakteristikker af den borgerlige frihed ikke mere abstrakte end Grundtvigs, hvilket jeg om lidt skal vende tilbage til. Et andet eksempel på den ukritiske overtagelse af Grundtvigs synspunkter er Birkelunds beskrivelse af, hvad han kalder "Pennekampen med H. N. Clausen" (148-154), hvor Clausen end ikke kommer til orde. I det hele taget synes Clausen at være en noget dunkel skikkelse for Birkelund. For eksempel læser man på side $435 \mathrm{i}$ forbindelse med et citat fra Hegels retsfilosofi, at "Der er her tale om et hegelsk udsagn [om forholdet mellem stat og kirke, se Grundlinien der Philosophie des Rechts (1821) §270], som givetvis har haft virkningshistorisk betydning for Clausen." Herved overses, at H. N. Clausen såvel i Det Nye Testaments Hermeneutik (1840), i Udvikling af de christelige Hovedlcerdomme (1844) og i sine erindringer udgivet i 1877 var en skarp kritiker af alt hegelsk. At dette er tilfældet, er da også Jørgen Larsens opfattelse i disputatsen fra 1945 om Clausen.

Det anatema, som ramte Kant hos Grundtvig, rammer ham også hos Birkelund. Kant fremstår her som en tænker, der ikke har sans for følelsernes rolle i det menneskelige bevidsthedsliv, og som har et unuanceret kvindesyn (495 f. og note 1384 på samme side). Nu overses det ofte, at i Kants moralfilosofi er den subjektive grund til moralsk handlen en følelse, nemlig agtelse for loven. Ligesom David Hume vidste Kant, at en blot og bar viden ikke udløser en handling, hvis den ikke er forbundet med en følelse, og som en slags elev af Rousseau lå en generel nedvurdering af følelserne ham fjernt. I forbindelse med sin påstand om Kants stedmoderlige behandling af følelser henviser Birkelund til Grundlegung zur Metaphysik der Sitten (1785). Kants opfattelse af følelseslivet skal dog ikke findes i hans transcendentalfilosofi, men i hans Anthropologie in pragmatischer Hinsicht abgefasst (1798), hvor behandlingen af det menneskelige følelsesliv langtfra er stedmoderlig. (Til oplysning: Der findes en dansk oversættelse fra 1802). Kant accepterede fuldt ud J. N. Tetens' psykologiske tredeling af bevidsthedsytringer i forestillinger, følelser og viljesytringer, og som Rousseau tilskrev han følelserne en selvstændig rolle i menneskets mentale konstitution. Og Kants syn på kvinden må tage sit udgangspunkt i det førkritiske skrift Beobachtungen über 
das Gefühl des Schönen und Erhabenen fra 1764, hvor Kant kalder kvinden for det ædle køn.

Det, der var Kant og Grundtvig imellem, var netop synet på følelserne. I overensstemmelse med langt de fleste filosoffer og psykologer i nyere tid tilskrev Kant ikke følelserne nogen erkendelsesværdi. Kun i den leibniz-wolffske psykologi blev følelserne og lidenskaberne opfattet som uklar erkendelse. Grundtvigs syn på følelserne som erkendemidler fremgår af det citat fra en af hans rigsdagstaler fra 1866, et citat, som Birkelund anfører på side $276 \mathrm{i}$ ufuldstændig form (ordet "sand" mangler): "sund Forstand paa Livet er hverken Meer eller Mindre end en sand Følelse, der bliver sig selv klar" (jf. US X, 573). Kant ville aldrig tale om en sand følelse. Det ville have været interessant, hvis Birkelund havde forsøgt at gøre klart, hvad Grundtvig mente om følelserne som erkendekilde. Umiddelbart lyder det som noget vrøvl at tale om en følelse, der kan blive sig selv klar. Hvis udtalelsen skal tages for pålydende - og det skal den vist, da Grundtvig giver udtryk for samme opfattelse i Nordens Mythologi (1832, US $\mathrm{V}, 433$ ) - bliver den klargørelse, der er tale om, en slags refleksiv akt. Men enhver ved af egen erfaring, at refleksion over en følelse dræber denne. Grundvig synes også at identificere det at have forstand på noget, for eksempel på livet, med erkendeevnerne.

Det lille ord "givetvis" i det tidligere anførte citat fra side 435 i afhandlingen giver mig anledning til at påtale Birkelunds overdrevne anvendelse af overtalende udtryk som for eksempel "det er oplagt" ( $\mathrm{fx}$ 70, 231), "sandsynliggør" (fx 237), "tydeligvis" (fx 561), "der kan ikke herske tvivl om" (fx 565). Den retoriske brug af sådanne udtryk har ofte den stik modsatte virkning end tilsigtet. Læseren standser op og begynder at fundere over, om der kan spores en anelse af tvivl i forfatterens sind, eller om det synspunkt, der er tale om, opfattes af forfatteren som så indlysende rigtigt, at der ingen grund er til at argumentere for dets rigtighed. Og så begynder man så småt at overveje, om det sagte virkelig er så indlysende, som forfatteren hævder. Måske er disse udtryk blot tegn på, at forfatteren mangler argumenter.

Efter den brede beskrivelse af udvalgte dele af den politiske filosofis historie i nyere tid følger afhandlingens første del, som er betitlet "Den græske Grundtvig - frihed, lighed og venskab" (133315). Det er her, at tesen om "den græske Grundtvig" skal præciseres og begrundes.

Birkelund er af den $\mathrm{i}$ og for sig rigtige opfattelse, at Grundtvigs ytringer om borgerlig frihed skal betragtes i deres historiske kontekst. Som især den engelske kender af den politiske filosofis historie Quentin Skinner har understreget, gælder dette for alle politiskfilosofiske tekster. De er, hvilket både Collingwood og Gadamer har 
hævdet, svar på problemer og spørgsmål i forfatternes samtid, og det er idehistorikerens opgave at finde ud af, hvilke problemer og hvilke spørgsmål teksterne var svar på. For eksempel kan Machiavellis Il Principe (1532) og Frederik den Stores L'antimachiavel (1740) kun fuldt ud forstås ud fra den politiske situation, som de to forfattere befandt sig i. Men når dette er tilfældet, skal man være varsom med at sammenligne politiske tekster forfattet $\mathrm{i}$ historisk og politisk forskellige kontekster. Lige så rigtigt det er at opfatte Grundtvigs ytringer om frihed som kontekstafhængige, lige så forkert er det, at Birkelund ikke lader det samme gælde for de forfattere, hvis politisk-filosofiske overvejelser sammenlignes med Grundtvigs.

Af de mere abstrakte formuleringer af, hvad der ligger i begrebet "borgerlig frihed", kan udledes nogle rettigheder. Disse rettigheder kan begrænses i større eller mindre grad under hensyntagen til samfundslivet. Den fortjenstfulde redegørelse, som udgør afhandlingens anden del (317-477), og som på glimrende måde supplerer tidligere redegørelser for Grundtvigs virke som rigsdagsmand, burde netop have udgjort materialet for en præcisering af de begrænsninger i rettigheder, som Grundtvig gik ind for under hensyntagen til almenvellet eller det "fælles Bedste", som Grundtvig skriver i for eksempel Mands Minde (1877), (MM, 70), og følgelig også til en præcisering og klargørelse af Grundtvigs begreb om frihed. Men en sådan præcisering og klargørelse foretager Birkelund ikke.

Gentagne gange lige fra 1804-dagbogen og i hvert fald frem til 7. oplag af Historisk Børne-Lardom fra 1867 anførte Grundtvig, hvad han forstod ved borgerlig frihed. Det første sted skrev Grundtvig:

Fuldkommen Lighed er en Sjimære - men Frihed til at udnytte sine Evner, uden at giøre Indgreb i andres fuldkomne Rettigheder, Frihed til at giøre hvad der ei strider med Moralens eller de borgerlige fornuftige Love — den er ønskelig[.] (Albeck 1979, 92).

Og 63 år senere skrev han, at

Menneske-Folkenes virkelige og lykkelige Frihed ikke bestaar i Flertallets Selvraadighed paa Papiret og paa Rigsdagene, men i en folkelig Styrelse og folkelig Lov og Ret, der sikrer alle Frihed til at tro, at tale og at gjøre, hvad de vil, naar de kun lader Ncesten nyde samme Skjel (Grundtvig 1890, 23-24).

Mellem disse to ret overensstemmende abstrakte bestemmelser af borgerlig frihed ligger adskillige andre, for eksempel i den første artikel om religionsfrihed fra 1827 (US V, 68), i en række af talerne i Danske Samfund (fx 10.3.1840 og 4.4.1843) og i Mands Minde (1877) (fx 80). De nævnte steder taler Grundtvig stort set på samme måde om borgerlig frihed, nemlig som friheden eller retten til at gøre, tro, tale 
og skrive, hvad man vil, så længe næstens tilsvarende rettigheder ikke beskæres. K. E. Bugge taler i denne forbindelse om det danske og det nordiske frihedsbegreb (Bugge 1965, 293) og Birkelund om græsk frihed (fx $177 \mathrm{f}$.).

Det er imidlertid interessant, at Grundtvigs frihedsopfattelse svarer ganske til for eksempel Kants og Fichtes. Kant havde allerede i Kritik der reinen Vernunft (1781) fastslået, at

Eine Verfassung von der grössten menschlichen Freiheit nach Gesetzen, welche machen, dass jedes Freiheit mit der anderen ihrer zusammen bestehen kann (nicht von der grössten Glückseligkeit, denn diese wird schon von selbst folgen), ist doch wenigstens eine nothwendige Idee, die man nicht blos im ersten Entwurfe einer Staatsverfassung, sondern auch bei allen Gesetzen zum Grunde legen muss, und wobei man anfänglich von den gegenwärtigen Hindernissen abstrahieren muss, die vielleicht nicht sowohl aus der menschlichen Natur unvermeidlich entspringen mögen, als vielmehr aus der Vernachlässigung der ächten Ideen bei der Gesetzgebung (A316).

Og i Metaphysik der Sitten (1797) udtrykkes samme tanke i form af retslærens grundlæggende princip, som lyder: "Eine jede Handlung ist recht, die oder nach deren Maxime die Freiheit der Wilkür eines jeden mit jedermanns Freiheit nach einem allgemeinen Gesetze zusammen bestehen kann" (Einleitung in die Rechtslehre, §C). Og måske endnu mere overensstemmende med Grundtvig skriver Fichte i Grundlage des Naturrechts nach Principien der Wissenschaftslehre (1796):

Ich schreibe mir selbst nicht alle Freiheit zu, die ich gesetzt habe, weil ich auch andere freie Wesen setzen und denselben einen Theil derselben zuschreiben muss. Ich beschränke mich selbst in meiner Zueignung der Freiheit dadurch, dass ich auch für Andere Freiheit übrig lassen. Der Begriff des Rechts ist sonach der Begriff von dem nothwendigen Verhältnisse freier Wesen zu einander (Her citeret efter bind 3 i Fichte $(1845,8)$.

Det fremgår af Skribenten Nik. Fred. Sev. Grundtvigs Literaire Testamente (1827), at Fichte var en af den unge Grundtvigs helte (US $\mathrm{V}, 162$ ), og den modne Grundtvigs totale afstandtagen fra den tyske idealisme ufortalt kunne Birkelund måske indledningsvis have drøftet en mere nærliggende inspiration til Grundtvigs begreb om borgerlig frihed end den græske. For øvrigt ville både Kant og Fichte være enige med Grundtvig om, at "Frihed er Aandens Element, som Tvang er Kroppens" (US V, 86).

I Verdenskrøniken fra 1812 nævner Grundtvig, at en række græske bystater $\mathrm{i}$ det 2 . århundrede $\mathrm{f}$. Kr. forsøgte at "fornye Frihedens glimrende Tider" (US II, 206), og i manuskriptet til de historiske fore- 
drag, som han i årene 1839-1844 holdt for dronningen og en snæver kreds af indbudte, hedder det, at

Grcekerne eller, som de kaldte sig selv, Hellenerne, satte som bekendt i den blomstrende Tid Friheden over alt andet, men det var ikke en dyrisk Frihed til at æde hinanden, men en menneskelig Frihed til i Selskab med ligesindede at udvikle sine Kræfter, nytte og nyde Livet uforstyrret, og derfor finder vi allerede i "Iliaden" og "Odysseen" lige saa mange uafhængige Fyrster, som der var Stater og Øer" (Grundtvig 1911, 151).

Grundtvig har fuldstændig ret $\mathrm{i}$, at de græske bystaters frihed bestod $\mathrm{i}$ deres uafhængighed og selvberoenhed. Det samme gælder for det fri menneske, det vil sige det menneske, hvis handlinger er frivilligt udført, eller - som Aristoteles siger det i den nikomacheiske etik - hvis handlinger har sit udspring (arché) i ham selv (Eth. Nic. 1110a), og som derfor ikke er udført under tvang. Det er interessant, at Grundtvig her slutter fra det faktum, at de græske bystater under perserkrigene kunne forsvare deres frihed, til at bystaternes indbyggere ikke kun havde bopæl og "Lysten til at raade sig selv" tilfælles, men at de også for en stor dels vedkommende var fælles om "Tankegang, Minder, Modersmaal og Dannelse". Hertil tilføjer han, at dette fællesskab "er de skjulte Betingelser for varm Fædrelandskærlighed og levende Sammenvirkning med Selvopofrelse, det har man siden glemt, men er nu dog paa Vej til at lære igen" (Grundtvig 1911, 153). Der kan ikke være tvivl om, at Grundtvig anså "Frihedens glimrende Tider" som et forbillede.

Det fremgår af de historiske foredrag, at den epoke i Grækenlands historie, som Grundtvig betragtede som "Frihedens glimrende Tider", strækker sig fra omkring det 8. århundrede f. Kr. til langt ind i det 5. århundrede f. Kr. I denne blomstrende tid var der, siger han, intet akademi i Athen (ibid., 154). Det var der i det 4. århundrede f. Kr., Platons og Aristoteles' århundrede. Efter det heltemodige forsvar mod perserne forvandledes, skrev Grundtvig i forste bind af Haandbog $i$ Verdens-Historien, "den Graeske Friheds-Aand" til "en Hersker-Aand, og gik derved med stærke Skridt sin Undergang imøde" (US VI, 276). Grundtvigs begejstring for den "græske frihed" kan derfor ikke bruges som argument for, at Platon og Aristoteles har betydet noget særligt for ham. Og der skal bedre argumenter til for at begrunde, at tankegange hos Platon og Aristoteles har inspireret Grundtvig, end at hæfte sig ved, at han havde deres værker stående i sit bibliotek og endda, som det lidt benovet meddeles i forbindelse med Aristoteles, både på græsk og latin (237). Auktionskatalogen viser, at Grundtvig ved sin død besad samtlige overleverede værker af Platon og Aristoteles og ikke kun, som det siges side 237 for Aristoteles' vedkommende, “de 
fleste". Men vi ved ikke, hvornår Grundtvig har anskaffet disse værker eller om - og i så fald hvornår - han har studeret dem. En fortegnelse på over 8.000 bibliografiske enheder i et efterladt bibliotek kan ikke bruges til ret meget, hvis ikke de nævnte oplysninger foreligger, eller hvis der ikke findes supplerende oplysninger fra bibliotekers låneprotokoller.

Som Birkelund anfører i note 641 (226 f.), skrev Grundtvig i Verdenskrøniken fra 1812, at han kendte meget lidt til Platon, men det synes klart, at

han var en ydmyg, sandhedskærlig Grubler, der vel af sin Tids Aand lod sig forlede til megen Spidsfindighed, men dog med alvorlig Omhyggelighed sankede de Lysglimt Aanden kunde faae Øie paa i sig selv og i Oldtidens Sagn. (US II, 397).

At denne kortfattede og ikke videre dækkende beskrivelse af Platon skulle, som Birkelund skriver, "tyde på et ikke ringe Kendskab til Platon", lyder lidet overbevisende. Platon fremtræder ikke som en ydmyg skikkelse i sine skrifter, og det var så som så, hvad han sankede "i Oldtidens Sagn". Birkelund påstår dernæst, at Grundtvig i første bind fra 1833 af Haandbog $i$ Verdens-Historien demonstrerer, at hans kendskab til Platon og Aristoteles er blevet udvidet siden den første verdenskrønikes fremkomst. Den korte omtale af Platons store dialog Staten i første bind af håndbogen (US VI, 298), hvor dialogen siges at fremmane en frustreret forfatters "søde Drøm", tyder dog ikke på et indgående Platon-studium.

At "Staten" skulle have inspireret Grundtvig til andet end en kraftig afstandtagen fra det statsideal, som Platon skildrer i dialogen, er der intet belæg for. Birkelund skriver på side 230, at regenterne i Platons stat, det vil sige filosofferne, havde det gode samfund for øje, hvilket ikke er tilfældet. Platons ideal var den retfærdige stat, det vil sige den stat, hvor de lige blev behandlet på samme måde, og de ulige på forskellig måde, idet det for Platon var uretfærdighed at behandle de ulige ens. Skønt Grundtvig i Nordens Mythologi (1832) kalder Platon "den guddommelige", fordi han prøvede at finde den "levende TankeKiæde", der forbinder jord og himmel (US V, 434), kaldte han i sidste bind af håndbogen Platons stat for en almægtig furie, på hvis alter alt, hvad der "er Menneske-Hjertet dyrebart", ofres (US VII, 390). Begge disse vurderinger af Platon citeres loyalt af Birkelund (70 og $236 \mathrm{f}$.).

Birkelund synes især at mene, at Platons pædagogiske ideer kunne have været inspirerende for Grundtvig. Der er imidlertid hos Platon ikke tale om, at samfundsborgerne skal opdrages på samme måde. Håndværkerne (som er styret af deres begær og er den nederste kaste i den platoniske stat) skal opdrages til loyalt at overholde filosof-monarkens bud, vogterne, eller krigerkasten (hvis hoveddyd er modet) skal 
opdrages til gode krigere, og filosofferne, herskerkasten, til indsigtsfulde personer. Vi er milevidt fra Grundtvigs forestilling om den "vidskab" der skal formidles på livets skole, og opfattelsen af staten som en fornuftkonstruktion har næppe heller tiltalt Grundtvig.

Al sand erkendelse, skriver Birkelund, var for Platon af eksistentiel art, da den ligger "latent i sjælen og venter på at blive forløst og gjort aktiv i det etiske handlingsliv" (554). Dette kan med nogen ret siges om Sokrates, der med Ciceros udtryk hentede filosofien fra himlen ned på jorden (Cicero, Tusc. Disp. V, 10); men for Platon drejede det sig i høj grad om begrebsafklaring. I en række af de sene dialoger, fx Parmenides, ses tydelige tendenser til en abstrakt og metafysisk tankegang. Og for Platon var den geometriske erkendelse det ideal, filosofien skulle leve op til. Det er lidt af en frihåndstegning af Platon, Birkelund præsenterer læseren for.

Det antydes også, at Platons kvindesyn skulle have inspireret Grundtvig, hvilket lyder besynderligt i betragtning af, at man var fælles om kvinderne i Platons stat. Birkelund bygger her på den forkerte opfattelse, at udgangspunktet for Platons kvindesyn fremgår af Aristofanes' myte om, at menneskene oprindeligt havde to sæt kønsorganer; men han overser, at myten kun er et spøgefuldt indslag blandt flere andre seriøse i Platons dialog "Symposion", og at disse oprindelige væsner enten var udstyret med to sæt kvindelige kønsorganer eller to sæt mandlige eller et af hver slags.

Birkelund er også selv i det korte afsnit med titlen "Platons 'kommunisme'" (234-237) inde på, at der kun var ganske få elementer i den platoniske tænkning, som Grundtvig kunne acceptere, men skriver, at Grundtvig var enig med Platon i, at erkendelse "dybest set drejer sig om selv-erkendelse". Men hvis dette skulle være et argument for Platons betydning for Grundtvig, kunne det med fuld ret også bruges til at påvise et utal af andre tænkeres indflydelse på den grundtvigske tankeverden. Man behøver blot at nævne, at så forskellige filosoffer som Descartes, Leibniz, Hume, Kant og Hegel kunne komme på tale. Og indskriften "Kend dig selv" fra Apollon-templet i Delfi stod ikke skrevet over indgangen til Platons akademi. Derimod stod der, at her lades ingen ind, der ikke er kyndig i geometri. Med sin afhandling ønsker Birkelund at sandsynliggøre, at elementer i Grundtvigs tankeverden er inspireret af Platon og Aristoteles (67); men for Platons vedkommende er det i hvert fald ikke lykkedes ham.

Og så kommer turen til Aristoteles, hvor især Aristoteles’ lære om venskabet har Birkelunds interesse.

Den Aristoteles, som vi møder i Birkelunds fremstilling, er en noget socialdemokratisk udgave af den gamle filosof med løgstrupske overtoner. Både Platon og Aristoteles tilskriver mennesket et etisk 
potentiale, hvilket er ret intetsigende, idet enhver handling, som et menneske udfører, og enhver viden, som det opnår, må det have haft mulighed, det vil sige potentiale, for henholdsvis at udføre og at opnå. Menneskene udfører også slette og onde handlinger og har derfor også et potentiale for ondskab. Skønt Aristoteles' forestilling om menneskets etiske potentiale forudsætter et helt andet begreb om erkendelse og et helt andet syn på etik end Platons, var de dog enige om, at virkeliggørelsen af potentialet for enten at handle moralsk forsvarligt eller moralsk forkasteligt afhænger af de påvirkninger, som mennesket udsættes for.

Birkelund hævder på side $242 \mathrm{f}$, at "begrebet venskab er det altafgørende omdrejningspunkt for Aristoteles", og at venskab for Aristoteles var betingelsen "for det gode liv, for det gode samfund", jf. også side 552, note 1525 , hvor det samme siges.

Den eudamonistiske etik, som Aristoteles udviklede i Ethica Nicomachea, er en individualetik, hvortil lægger sig en socialetik. Det er $\mathrm{i}$ forbindelse med den sidste, at begrebet "venskab" er centralt. Menneskets mål er at opnå lykke, det vil sige at erhverve så mange goder som muligt. Goder kan for eksempel være rigdomme, gode børn og venskaber, og i almindelighed forudsætter lykke ydre ting. Muligheden for at opnå goder forudsætter kløgt eller livsvisdom, på græsk

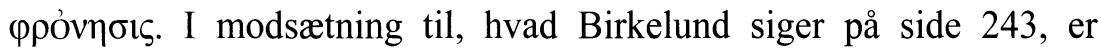
kløgten ikke identisk med evnen til at vinde venner, men er evnen til at opnå goder $\mathrm{i}$ almindelighed, herunder også venner.

Venskab var for Aristoteles flere forskellige ting. Der findes, skriver han i Eth.Nic. 1156a, tre former for venskab. Hver form er betinget af grunden til, at der stiftes venskab, eller, som Aristoteles ville sige, hvorfor man elsker en anden. Dette kan være for nyttens skyld, eller for lystens skyld. I disse to former for venskab elskes den anden ikke for sin egen skyld, og sådanne venskaber er tilfældige. Venskaber for nyttens eller for lystens skyld opløses, når den anden ikke længere er et nyttigt middel til at opnå noget, eller når han ikke længere opleves som behagelig at være sammen med. Endelig er der de venskaber, hvor den elskede elskes for sin egen skyld. Disse venskaber er de mest fuldkomne.

Ifølge indledningen til Aristoteles' statslære (Politica) er staten et fællesskab, som er opstået med et formål for øje, nemlig for at det enkelte menneske kan opretholde livet og erhverve sig goder (1252ab). Fællesskabet er således til med henblik på den nytte, som de enkelte samfundsborgere kan have af hinanden i forbindelse med deres naturgivne stræben efter lykke. Fællesskabet er opstået af hensynet til nytten, og det vil være i overensstemmelse med Aristoteles' tankegang 
at sige, at et nyttebetinget venskab både er betinget af et fællesskab og er medvirkende til, at dette fællesskab opretholdes.

Umiddelbart synes Grundtvigs opfattelse af staten at være en ganske anden end Aristoteles'. I Statsmoessig Oplysning tager Grundtvig eksplicit afstand fra den tanke, at staten skal varetage "EnkeltMandens" interesser (Bugge og Nielsen 1983, 28). Det borgerlige samfund, skrev Grundtvig her, er baseret "paa en vis Grund-Enighed om det almindelige Bedste", og hvis der i en stat findes både en herskerklasse og en slavestand (som i den græske og hos Platon og Aristoteles), er denne grundenighed ikke opnået. (58 f.). Umiddelbart synes der at være en himmelvid forskel mellem Platons og Aristoteles' statsopfattelser og Grundtvigs.

På side 243 anfører Birkelund en definition på venskab hentet fra Eth.Nic 1166a, en definition, som Aristoteles bruger til at vise, at de følelser, der karakteriserer venskab, udspringer af menneskets egenkærlighed, det vil sige af dets følelser for sig selv. Alt efter hvad der er baggrunden for et venskab, opregner Aristoteles fem grunde til, at der opstår venskab. Det kan enten være, (1) fordi man ønsker ethvert gode for den anden, eller (2) fordi man ønsker, at han skal leve, eller (3) fordi man lever sammen med vedkommende, (4) har den samme smag som ham, eller (5) deler sorger og glæder med ham. Birkelund slår de to første grunde til venskab sammen og betragter denne sammenkobling som Aristoteles' definition af venskab. Men herved overser Birkelund, at der ikke kun er en form for venskab, men tre.

På side $242 \mathrm{f}$. citeres Aristoteles for at sige, at "Hvad der holder staten sammen, er vel egentlig venskab" (Møller 1936/1995, 161). Hvis Birkelund havde valgt at bruge den nyeste oversættelse af den nikomakeiske etik, ville det samme sted hos Aristoteles være oversat til "Også bystaterne synes at være forbundet igennem venskabet" (Porsborg 2000, 195, 1155a). Er det den enkelte bystat, der holdes sammen af venskab, eller er det forholdet mellem bystaterne, Aristoteles her taler om? Hvis Birkelund havde valgt at bruge W. D. Ross' meget benyttede engelske oversættelse i den af Ross redigerede The Works of Aristotle translated into English, bind 9, ville han måske finde, at begge tolkninger af det pågældende sted hos Aristoteles er mulige. $\mathrm{Nu}$ fremgår det ikke af afhandlingen, at Birkelund har konsulteret andre oversættelser af Eth.Nic. end Møllers. Men hvis han havde gjort det, havde han haft et problem.

Eksemplet viser, at hvis man ønsker at sammenligne to forfatteres udtalelser, bør man gå ud fra originalteksten. Det virker besynderligt, at man i en anmeldelse af en disputats skal gøre opmærksom på dette.

Og hvad siger så originalteksten? For det første optræder det græske ord for bystat $\mathrm{i}$ bestemt flertalsform, for det andet fremgår det af 
sammenhængen, at der er tale om, at sammenhængskraften i den enkelte bystat er betinget af venskab. For så vidt har Birkelund været heldig. Men ud fra Aristoteles' opfattelse af statens formål og hans redegørelse for de forskellige former for venskab, må det venskab, der er tale om, være et, der er baseret på nyttehensyn. Og er det denne form for venskab, Grundtvig taler om? Dette spørgsmål lades fuldstændig ude af betragtning. På side 249 skriver Birkelund, at selvfølgelig havde Grundtvig ikke kun sin utopi om "det gode, retfoerdige og venskabelige samfund" fra de gamle grækere, men han havde den også fra dem: "Det gamle Grækenlands statshistorie og de græske filosoffer spillede en ganske betydelig rolle for ham, og ikke mindst Aristoteles' tanker om venskab og det venskabelige samfund ser ud til at have sat sig dybe spor hos Grundtvig."

Den konklusion er Birkelund nået frem til på baggrund af en overfladisk sammenligning mellem oldgræske tekster i dansk oversættelse og grundtvigske tekster. Han har fremdraget begreber såsom frihed og venskab, men har overset distinktioner og ladet begreberne henstå fuldstændigt uanalyserede og for Aristoteles' vedkommende som kontekstuafhængige. Stiltiende synes Birkelund at antage, at Aristoteles' begreb om venskab stort set var det samme som Grundtvigs. Det kan ikke afvises, at Grundtvig har været inspireret af Platon og Aristoteles; men ud fra Grundtvigs egne udtalelser om dem kan tesen ikke begrundes, og Birkelund har ikke formået at sandsynliggøre deres indflydelse på Grundtvigs tankeverden.

Efter den centrale 1. del om "Den græske Grundtvig" følger, som tidligere nævnt, i 2. del en fyldig redegørelse for Grundtvigs indsats som rigsdagsmand. 3. del, "Kampen for kvindens og det kvindeliges frigørelse" (479-534), blev ved det mundtlige forsvar skarpt kritiseret, og jeg skal ikke her knytte kritiske bemærkninger til det. Afhandlingen afsluttes med en 4. del, "Et kvindeligt oplysnings- og frigørelsesprojekt" (537-636), som er en lidt ufokuseret omtale hovedsagelig af Grundtvigs skoletanker, en "Sammenfattende afslutning" (637-652) og et engelsk resumé.

Begrebet om frihed er et centralt, men uklart begreb hos Grundtvig, og en videnskabelig afklaring af det er højst ønskelig. Han undervurderede ikke kravet om klarhed, men, som han skrev i Nordens Mythologi (1832), er klarhed "vel nødvendig Maalet for Alt hvad der er Liv og Aand bevidst, men just fordi den er Maalet og Kronen, just derfor kan den umueligt tillige være Vandrings-Staven paa Veien" (US $\mathrm{V}, 394)$. Men Grundtvig synes aldrig at være kommet til målet, det vil sige klart at få præciseret begrænsningen ud fra hensynet til det fælles bedste af de rettigheder, der følger af hans abstrakte begreb om borgerlig frihed. Heller ikke Birkelund har frembragt den ønskede klarhed. 
Som Grundtvig sagde, hører de tykke bøger sædvanligvis ikke til de bedste. Der findes undtagelser, men blandt disse findes den her anmeldte bog ikke. Man må håbe at Birkelunds afhandling vil inspirere til en egentlig videnskabelig analyse af Grundtvigs frihedsbegreb.

\section{Litteraturliste}

Albeck, Gustav (red.) (1979), N. F. S. Grundtvig Dag-og Udtogsbøger, København.

Bugge, K. E. (1965), Skolen for Livet: Studier over N. F. S. Grundtvigs padagogiske tanker, København.

Bugge, K. E. og Nielsen, Vilhelm (udg.) (1983), N. F. S. Grundtvig: Statsmaessig Oplysning. Et udkast om samfund og skole, København.

Fichte, J. G. (1845), Sämmtliche Werke, Berlin.

Grundtvig, N. F. S. (1890), Historisk Børne-Lardom, 9. oplag, København.

- (1911), Historiske Foredrag 1839-1844 i Udkast, Den Grundtvigske Folkeskriftfond, København.

Kant, Immanuel og Voländer, Karl (1785), Grundlegung zur Metaphysik der Sitten, (vierte Auflage, 1797), Riga.

Laslette P. (ed.) (1967), J. Locke, Two Treatises of Government (1890), The Second Treatise, chap. XII, 2 ed., Cambridge.

MM: Svend Grundtvig (udg.) (1877), Mands Minde 1788-1838. Foredrag over det sidste halve Aarhundredes Historie, holdte 1838 af Nik. Fred. Sev. Grundtvig, København.

Møller, Niels (ovs.) (1936/1995), Aristoteles, Den Nikomacheiske Etik, Frederiksberg.

Porsberg S. (ovs.) (2000), Aristoteles, Etikken, Frederiksberg.

US X: Bind 10 i Holger Begtrup (udg.) (1904-09), Nik. Fred. Sev. Grundtvigs Udvalgte Skrifter, bind 1-10, København.

Ross, W. D. (ed.) (1908-1952), The Works of Aristotle translated into English, vol. 9, Oxford. 